\title{
DOMINASI PARTAI GOLKAR DI KABUPATEN TANAH DATAR PADA PEMILIHAN LEGISLATIF TAHUN 2014
}

\author{
Okadarmi Dwi Kaypama \\ Jurusan Ilmu Politik, Fakultas Ilmu Sosial dan Ilmu Politik, Universitas Andalas \\ Email: Okadarmi92@gmail.com
}

\begin{abstract}
Abstrak
Kemenangan dan dominasi Partai Golkar telah dirasakan oleh rakyat dan terlihat jelas baik di tingkat Nasional maupun Lokal. Partai Golkar menjadi Partai terkuat meski mengalami masamasa sulit. Bagi Partai Golkar di era reformasi membawa tantangan tersendiri. Namun pada kenyataannya, Partai Golkar masih ada dan tetap kuat selama beberapa dekade di Sumatera Barat, terutama di Kabupaten Tanah Datar. Terbukti dengan perolehan suara tertinggi setiap pemilu hingga Pemilu Legislatif 2014 yang mencapai 77.504 suara memenangkan delapan kursi di DPRD Kabupaten Tanah Datar. Hasil penelitian ini menemukan bahwa penyebab Partai Golkar yang dominan adalah karena 1) manajemen organisasi sistemik, 2) penerapan platform partai suara Golkar, suara rakyat, nilai-nilai yang ditanamkan dalam anggota, 3) ada jaringan yang memberikan dukungan seperti tokoh masyarakat, tokoh ulama, hingga strata masyarakat. 4) citra positif yang telah dibangun oleh Partai Golkar kepada masyarakat, penggunaan budaya masyarakat untuk lebih dekat dan menarik pemilih. Temuan lain dalam penelitian ini adalah masih dirasakan terkait sistem Orde Baru oleh Pegawai Negeri Sipil (PNS) memilih Partai Golkar dan ada juga peran kelompok tradisional atau kearifan lokal yang memiliki afiliasi politik dengan Golkar.
\end{abstract}

Kata Kunci : Dominasi ; Partai Golkar

\begin{abstract}
The winning and dominance of the Golkar Party has been felt by the people and is seen clearly both at the National and Local levels. The Golkar Party became the strongest Party despite having hard times. For the Golkar Party in the reform era brought its own challenges. But in reality, the Golkar Party still exists and has remained strong for decades in West Sumatra, especially in Tanah Datar District. Evidenced by the highest vote acquisition every election until the 2014 Legislative Election which reached 77,504 votes won eight seats in the Tanah Datar District Parliament. The results of this study found that the dominant cause of the Golkar Party was due to 1) systemic organizational management, 2) the application of the Golkar vote party platform, the voice of the people, the values that are instilled in members and reach out to the community, harmonious and communicative relations among members. 3) there is a network that provides support such as community leaders, ulama figures, to community strata. 4) positive image that has been built by the Golkar Party to the community, the use of the culture of the community to get closer and attract voters. Another finding in this study is that the New Order system still feels that Civil Servants (PNS) chose the Golkar Party and there is also the role of traditional groups or local wisdom who have political affiliation with Golkar.
\end{abstract}

Keywords: Domination ;Golkar Party 


\section{PENDAHULUAN}

Kehadiran Partai politik dalam suatu negara yang demokratis merupakan suatu keharusan, karena keberadaannya merupakan salah satu instrumen utama demokrasi. Partai politik pada hakikatnya adalah sebuah suprastruktur yang harus dimiliki sebuah sistem pemerintahan agar dapat dikatakan sebagai sistem pemerintahan yang demokratis. Untuk memaksimalkan fungsinya sebagai bangunan yang mendukung pemerintahan yang demokratis, sebuah Partai haruslah terlembagakan. ${ }^{1}$ Pelembagaan Partai politik yang dimaksud adalah, merupakan proses pemantapan sikap dan perilaku Partai politik yang terpola atau sistemik sehingga terbentuk suatu budaya politik yang mendukung prinsip-prinsip dasar demokrasi. Dinamika politik kepartain sangat dinamis dan banyak mengalami berbagai perubahan, diantara tiga Partai politik yang pernah eksis ketika orde baru ${ }^{2}$, Partai Golkar yang menjadi Partai penguasa atau mendominasi menjadi Partai yang menghadapi masa-masa paling sulit sepanjang sejarah setelah sebelumnya menikmati semua kemewahan politik. ${ }^{3}$

Dominasi adalah sebuah paham untuk melakukan penaklukan atau penguasaan terhadap lainnya dalam hal ini bisa kita lihat adanya penguasaan dari segi perolehan suara oleh Partai Golkar. Isitiah dominasi politik populer ketika dikembangkan oleh Partai Golongan Karya di Indonesia untuk melambangkan dominasinya yang berdasarkan kuantitas dengan semboyan "mayoritas pendamping yang mendekati kebesarannya. ${ }^{4}$ Dominasi Partai Golkar memang sudah dirasakan sejak dulunya hasil dari pemerintahan orde baru. Setelah reformasi dengan bermunculannya Partai politik lain tidak mempengaruhi suara Partai Golkar di Sumatera Barat, di balik fenomena ini tentunya ada pemicu, peneliti mengasumsikan bahwa dominasi politik dari Partai Golkar dikarenakan adanya pelembagaan Partai yang tertata rapi dalam sistem Partainya. Partai Golkar dengan eksistensinya di Indonesia sampai ketingkat lokal dalam hal ini di Sumatera Barat sangat begitu jelas terasa dengan bukti kemenangan dalam pemilihan legislatif.

Daerah-daerah di Sumatera Barat baik itu Kota maupun Kabupaten menjadi penyumbang suara pemilih terbanyak Partai Golkar dalam pemilihan legislatif. Ada enam daerah dengan perolehan unggul suara Partai Golkar di Sumatera Barat. Peneliti sangat tertarik pada perolehan suara Partai Golkar di Kabupaten Tanah Datar yang mana

\footnotetext{
${ }^{1}$ Imansyah, Teguh, "Regulasi Partai politik dalam mewujudkan penguatan peran dan fungsi kelembagaan Partai politik", Jurnal Rechtsvinding, Vol 1 No.3, Desember 2012 : hlm. 5

${ }^{2}$ Orde baru merupakan era dimana Partai politik dikonstruksi sedemikian rupa oleh penguasa untuk melayani orientasi pembangunan yang menekankan pada pertumbuhan ekonomi. Perlahan tapi pasti peran Partai politik dibatasi dalam kehidupan politik dan kemudian dikendalikan oleh negara. Partai-Partai politik lama yang memiliki akar pada masa kemerdekaan, demokrasi liberal dan demokrasi terpimpin disingkirkan secara sistematis sembari negara mengkonstruksi satu kekuatan politik baru sehingga berujung pada era"dua Partai satu Golkar" dengan karakter sistem kepartaian.

${ }^{3}$ Ibid, hlm 159.

${ }^{4}$ Bungaran Anton Simanjuntak, "Strategi Dominasi Dan Keutuhan Negara Bangsa Yang Pluralistik", Jurnal Antropologi Sosial Budaya ETNOVISI. Volume I No.2, Oktober 2005, hal. 58
} 
akan menjadi lokasi penelitian peneliti karena mendominasi perolehan suara dibanding Kabupaten/Kota yang unggul juga dalam pemilihan legislatif pada tahun 2014, berikut datanya :

Tabel 1.

Perolehan suara unggul Partai Golkar di enam Kabupaten/Kota di Sumatera Barat pada Pemilihan Legislatif Tahun 2014

\begin{tabular}{cc}
\hline Nama Kab/Kota & $\begin{array}{c}\text { Peroleha } \\
\text { n suara }\end{array}$ \\
\hline Kabupaten Padang Pariaman & 40.393 \\
Kabupaten Solok & 35.896 \\
Kota Solok & 5.693 \\
Kabupaten Tanah Datar & $\mathbf{7 7 . 5 0 4}$ \\
Kabupaten Solok Selatan & 16.801 \\
Kabupaten Sijunjung & 22.125 \\
\hline Sumber : Diolah dari data KPU
\end{tabular}

Berdasarkan tabel di atas peneliti melihat bahwa terlihat jelas adanya dominasi perolehan suara Partai Golkar di Kabupaten Tanah Datar dengan perolehan suara tertinggi yaitu 77.504 suara. Menarik untuk diteliti apa penyebab dominasi Partai Golkar di Kabupaten Tanah Datar yang merupakan daerah yang selalu memberikan suara terbanyak untuk Partai Golkar sejak tahun 1999. Jika peneliti melihat homogenitas dan kultural masyarakat di Kabupaten Tanah Datar yang merupakan kebanyakan orang Minang dan hampir menyeluruh beragama Islam ternyata tidak terlalu berpengaruh terhadap voting behavior atau perilaku memilih masyarakat Tanah Datar itu sendiri untuk memilih Partai yang sesuai dengan basis agama maupun kesukuan masyarakat Minangkabau, walaupun dari tiga pemilihan Partai yang berbasiskan Islam seperti PKS dan PAN, tapi tetap saja tiga pemilu tetap dimenangkan oleh Partai yang bukan Partai berbasis islam, yaitu Partai Golkar.

Ilmuwan yang berusaha menelisik secara lebih spesifik tentang pelembagaan Partai adalah Randall dan Svasand. Dalam teorinya pelembagaan Partai politik adalah proses pemantapan Partai politik baik secara struktural dalam rangka mempolakan perilaku maupun secara kultural dalam mempolakan sikap atau budaya. Menurutnya, proses pelembagaan ini mengandung dua aspek, yaitu aspek internal-eksternal dan aspek struktural-kultural yang saling bertemu dalam persilangan sehingga menghadirkan aspek kesisteman. ${ }^{5}$

Dengan suara Partai Golkar di Kabupaten Tanah Datar yang mendominasi dibanding Partai lainnya kemudian memperoleh kursi terbanyak dalam setiap pilegnya, secara khusus pada pileg tahun 2014. Peneliti kuat mengasumsikan bahwa dominasi Partai Golkar ini terjadi karena adanya pelembagaan Partai politik yang terstruktur dan

\footnotetext{
${ }^{5}$ Sigit Pamungkas, Partai Politik- Teori dan Praktik di Indonesia, Institute Democracy and Welfarism, Yogyakarta, 2011, hlm. 74
} 
moderat yang nanti akan peneliti buktikan dengan teori pelembagaan Partai politik menurut Randall dan Svasand. Berdasarkan penjabaran di atas maka tujuan penelitian ini adalah untuk menggambarkan dan menganalisis penyebab Partai Golkar mendominasi di Kabupaten Tanah Datar pada pemilihan legislatif tahun 2014. Untuk mengungkapkan hal-hal baru dalam menganalisis penyebab dominasi Partai Golkar di Kabupaten Tanah Datar pada pemilihan legislatif tahun 2014.

\section{Konsep Dominasi}

Dominasi adalah penguasaan oleh pihak yang kuat terhadap pihak yang lebih lemah baik itu dibidang politik, militer, olahraga, dan sebagainya. ${ }^{6}$ Dominasi dapat diartikan sebagai kondisi di mana seorang individu ingin menguasai orang lain baik secara fisik maupun mental sehingga yang dikuasai akan mengikuti kemauan yang menguasai. ${ }^{7}$ Secara konsep bahwa kelompok dominan merupakan kelompok yang mendominasi sehingga mereka mampu untuk mengatur dan menguasai orang lain agar bertindak sesuai dengan kemauan dan kehendak mereka sendiri. Atau dalam kata lain dapat dikatakan bahwa terjadi pemusatan kekuasaan ditangan seorang individu atau kelompok atas individu atau kelompok lainnya.

Dalam penelitian yang akan peneliti ulas, peneliti memakai pemikiran Vicky Randal dan Lars Svasand dalam Party Institutionalization and the New Democracies yang menyatakan bahwa pelembagaan Partai adalah proses pemantapan Partai politik baik secara struktural mempolakan perilaku maupun secara kultural yang mempolakan sikap dan budaya. Terdapat empat dimensi penting dalam pelembagaan Partai politik yakni kesisteman organisasi, otonomi pengambilan keputusan, nilai-nilai yang terserap, dan reifikasi. ${ }^{8}$ Terdapat Dua aspek dari proses pelembagaan Partai politik Randall yang terdiri dari aspek internal-eksternal dan aspek struktural-kultural seperti pada tabel berikut

Tabel 2. Variabel Pelembagaan Politik

\begin{tabular}{lll}
\hline & Internal & Exsternal \\
\hline Structural & Systemness & Decisional Autonomy \\
\hline Attiudinal & Value Infusion & Reification
\end{tabular}

Sumber ; Randall dan Svasand

\footnotetext{
${ }^{6}$ Kbbi.web.id, “dominasi”, diakses di http://www.kbbi.web.id/dominasi, pada 02 Januari 2019, pukul 14.00

${ }^{7}$ Bungaran Anton Simanjuntak, Op-Cit Jurnal, hlm 57

${ }^{8}$ Vicky Randall dan Lars Svasand, "Party Institutionalization and the New Democracies, ECPR Joint Session of Workshop”, 26-31 Maret 1999, Mannheim : ECPR, hal. 9-10.
} 
Dimensi kesisteman organisasi, terkait dengan bagaimana pengelolaan lembaga tersebut dilakukan. Termasuk juga di dalamnya mengenai Partai dengan jaringan yang memadai dan cukup rinci yang mengakibatkan setiap keputusan Partai diikuti dan dilaksanakan oleh seluruh anggotanya. Setidaknya dalam artian formal, prosedural yang ditetapkan di dalam anggaran dasar dan anggaran rumah tangga lembaga tersebut diyakini sangat terinstitusionalisasi. Dimensi penyerapan nilai, terkait dengan kemampuan Partai untuk mengikatkan atau menghubungkan institusi ini dengan kelompok masyarakat. Partai bukan saja merupakan organisasi instrumental formal yang hanya menggarap keuntungan-keuntungan potensial melainkan juga sebagai aktor yang berperan membagikan ideologi dan mengidentifikasi anggota dengan nilai-nilai Partai tersebut. Dimensi otonomi pengambilan keputusan, mengacu terhadap hubungan Partai dengan ekosistem lingkungannya. Hal yang terpenting dari dimensi ini adalah, pertama, apakah Partai tergantung kepada aktor luar atau hubungan itu bersifat independen. Kedua, apakah keputusan Partai ditentukan oleh aktor luar atau hubungan itu berupa jaringan yang memberi dukungan kepada Partai.

Dimensi reifikasi, bahwa bagaimana Partai mampu memberikan citra kepublik yang mampu mengangkat nilai kesetiaan konstituen dalam memberikan dukungannya. Dari keempat dimensi menurut randall dan svasand tersebut adanya pandangan peneliti bahwa Partai Golkar di Kabupaten Tanah Datar dalam mendominasi suara dalam pemilihan legislatif tahun 2014 dapat dijelaskan dengan indikator dimensi tersebut.

\section{METODE PENELITIAN}

Penelitian ini menggunakan metode kualitatif dengan pendekatan analisi deksriptif. Uuntuk nanti menggambarkan dan menganalisis bagaimana dominasi Partai Golkar dalam mendominasi pemilihan legislatif di Kabupaten Tanah Datar pada pemilihan legislatif tahun 2014. Pendekatan Kualitatif merupakan prosedur penelitian, yang menghasilkan data deskriptif berupa kata-kata tertulis atau lisan dari orang-orang dan perilaku yang diamati. ${ }^{9}$

Pemilihan desain penelitian bersifat deskriptif analisis dalam menganalisis dominasi Partai Golkar di Kabupaten Tanah Datar nanti akan disajikan melalui katakata dan data setelah peneliti mendapat hasil wawancara untuk menggambarkan fenomena pelembagaan Partai yang diterapkan pada Partai Golkar di Kabupaten Tanah Datar dan kemudian penelitian deskriptif kualitatif ini diuraikan berdasarkan penuturan para responden. Penuturan dari responden tersebut sesuai dengan kaidah yang ada serta direduksi dan diverifikasi untuk kemudian disimpulkan sesuai dengan apa yang telah diperoleh. Peneliti akan kemudian akan menjelaskan sesuai dengan apa yang melatarbelakangi apa yang akan peneliti teliti.

\footnotetext{
${ }^{9}$ lexy J. Moleong, Metode Penelitian Kualitatif, Jakarta:PT Remaja Rosdakarya. 2002. hal, 3
} 


\section{HASIL DAN PEMBAHASAN}

\section{Dominasi Partai Golkar di Kabupaten Tanah Datar}

Dominasi dan Eksistensi Partai Golkar di Kabupaten Tanah Datar sudah terlihat dari bukti kemenangan sejak orde baru hingga tahun 2014, puncaknya adalah pada pemilihan legislatif tahun 2014 yang secara umum mendapatkan kemenangan signifikan mencapai 77.504 suara. Kemenangan ini merupakan kemenangan telak yang di dapat oleh Partai Golkar, pasalnya ini melebihi 50\% suara dari Partai pesaing lainnya. Pada pileg tahun 2014 ini pun menghantarkan fraksi Golkar mendapat delapan kursi DPRD Kabupaten Tanah Datar. Ini merupakan bentuk dari perjuangan Partai Golkar dalam memenangkan dan mempertahankan kekuasaannya sehingga menghasilkan dominasi di Kabupaten Tanah Datar. Ini sesuai dengan pemaparan Ketua DPRD Kabupaten Tanah Datar terpilih yang mengatakan ${ }^{10}$ :

...Pileg tahun 2014 sama pelaksanaannya dengan pemilu tahun-tahun sebelumnya, namun pada pemilu 2014 Alhamdulillah kami Partai Golkar mencapai hasil yang signifikan, perolehan tertinggi sebanyak 77.504 suara di Kabupaten Tanah Datar. Kalau secara akumulasi pusat, pada tahun 2014, Partai Golkar mencapai angka hampir 50\% dari jumlah pemilih yang hanya 177 ribu yang hadir, Golkar mencapai waktu itu sekitar 77 ribu lebih, berarti diatas angka $50 \%$.

Seperti yang kita tahu bahwa asal usul Partai Golkar yang sejak dulunya sudah menjadi penguasa politik atau mendominasi di Kabupaten Tanah Datar, terlihat pada perolehan kursi pemilihan legislatif. Berikut data bukti perolehan suara dalam pemilihan di Kabupaten Tanah Datar dari tiga kali pemilihan umum langsung legislatif, selalu memenangkan Partai yang sama yaitu Partai Golkar dengan perolehan kursi terbanyak setiap pemilihannya.

\section{Penyebab Dominasi Partai Golkar di Kabupaten Tanah Datar}

\section{Dimensi Kesisteman Organisasi}

Partai Golkar di Kabupaten Tanah Datar dengan kepengurusan yang dibentuk sejak dulunya dengan pengelolaan Partai yang berulang dan dinamis membuat kematangan Partai dalam pengelolaan organisasi. Systemness atau derajat kesisteman organisasi adalah proses pelaksanaan fungsi-fungsi Partai politik, termasuk penyelesaian konflik, dilakukan menurut aturan, persyaratan, prosedur dan mekanisme yang disepakati dan ditetapkan dalam Anggaran Dasar dan Anggaran Rumah Tangga (ART) Partai politik. AD / ART Partai politik dirumuskan secara komprehensif dan rinci sehingga mampu berfungsi sebagai kaidah dan prosedur penuntun perilaku dalam melaksanakan semua fungsi Partai politik.

\footnotetext{
${ }^{10}$ Wawancara bersama Bapak Anton Yondra S.E Ketua DPRD Kabupaten Tanah Datar 2014 sekaligus menjabat sebagai sekretaris DPD Partai Golkar Tanah Datar tahun 2014, pada tangga 27 Mei 2019 di Kantor DPRD Kabupaten Tanah Datar pukul 11.45
} 
Dalam derajat kesisteman menurut Randall dan Svasand meliputi ruang lingkup keanggotaan dan keberlangsungan interaksi yang membentuk Partai menjadi sebuah struktur, dan aturan yang yang ada mengandung derajat rutinitas dan perkembangan kebiasaan untuk menuntun perilaku individu. Tergambar dalam apa yang disampaikan oleh Ketua DPRD yang waktu itu menjabat sebagai sekretaris DPD Partai Golkar yang mengatakan bahwa ${ }^{11}$ :

...jadi sebenarnya kondisi yang terjadi terkait kemenangan Partai Golkar dan mendominasi, karena dari rekrutmen calon yang sangat matang kemudian selanjutnya setelah proses pencalonan ini selesai kita Partai Golkar, ibarat mesin Partai, mesinnya itu jalan. Kita selalu evaluasi, setiap persoalan kita lakukan cross check lapangan, kita lakukan kunjungan ke lapangan, kita kampanye door to door, seluruh caleg kita motivasi untuk mengumpulkan suara, istilahnya seluruh langkah sudah kita lakukan meski pada waktu itu kita tidak terlalu mendapat bantuan yang signifikan dari pusat, namun Alhamdulillah berkat caleg termasuk caleg Kabupaten, caleg provinsi dan caleg DPR RI nya bersinergi, akhirnya Partai Golkar berhasil mengantarkan yang pertama delapan anggota DPRD Kabupaten Tanah Datar, satu putra daerah sebagai anggota DPRD Provinsi dan satu putri daerah sebagai anggota DPR RI.

Dari hasil wawancara tersebut dapat peneliti ambil bahwa lembaga yang dapat menguasai internal Partai dengan baik merupakan lembaga yang dapat memberikan contoh yang baik pula ke sesama lembaga lainnya apalagi kepada masyarakat yang akan merasakan dampaknya. Aturan-aturan yang berlaku di dalam Partai dapat dijadikan acuan untuk menjalankan tugas dari fungsi masing-masing kader, tidak terbendung juga akibat dari adanya kader yang mumpuni untuk mengabdi tidak hanya di internal Partai namun juga mengabdi kepada masyarakat.

\section{Dimensi Penyerapan Nilai (Identitas Nilai Partai Politik)}

Penyerapan nilai dalam Partai politik itu terkait pada kemampuan Partai untuk mengikatkan dan menghubungkan diri dengan kelompok masyarakat. Identitas nilai Partai politik haruslah berdasarkan atas ideologi atau platform Partai, basis sosial dan pendukungnya dan identifikasi anggota terhadap pola dan arah perjuangan Partai. Partai bukan saja merupakan organisasi instrumental formal yang hanya menggarap keuntuntungan-keuntungan potensial melainkan juga sebagai aktor yang berperan membagikan ideologi dan mengidentifikasi anggota dengan nilai-nilai Partai tersebut.

Output dari penyerapan nilai dan adanya basis pendukung yang dapat menghantarkan Partai Golkar menjadi Partai yang mendominasi di Kabupaten Tanah Datar diutarakan oleh informan peneliti yang menjabat sebagai pengurus bidang organisasi di Kabupaten Tanah Datar :

\footnotetext{
${ }^{11}$ Wawancara bersama Bapak Anton Yondra S.E Ketua DPRD Kabupaten Tanah Datar 2014 sekaligus menjabat sebagai sekretaris DPD Partai Golkar Tanah Datar tahun 2014, pada tangga 27 Mei 2019 di Kantor DPRD Kabupaten Tanah Datar pukul 11.45
} 
...saya lihat hampir merata semua kelompok mendukung Golkar, Golkar sudah menang sejak dulunya, jadi keyakinan dari masyarakat untuk memilih Golkar sudah ada. Kemudian yang kedua yang mengajak adalah bupatinya, wakilnya. Ketua DPRD nya, orang Golkar semuanya. Masyarakat sudah tahu bahwa Golkar mengisi tokoh-tokoh sentral di Kabupaten Tanah Datar. Nilai-nilai yang ditanamkan untuk anggota : yaitu nilai kekaderan, yang pertama sekali selalu melihat keaktifan dari kadernya, di Kabupaten itu harus tau apa yang bisa dilakukan dari kekuatannya untuk nagarinya. Golkar punya kader yang bisa melihat orang-orang yang berpengaruh disetiap nagari dan jorongnya dan menjalin hubungan baik dengan tokoh-tokoh berpengaruh tersebut.

Alhasil dari yang telah peneliti tanyakan kepada beberapa informan jawabannya hampir sama bahwa memang dominasi Partai Golkar sudah mengakar hingga ke akarakarnya sehingga memudahkan untuk masuk sebuah nilai. Semakin kuat identitas nilai maka akan semakin kuat pula Partai dalam sebuah tatanan pemerintahan.

\section{Dimensi Pengambilan Keputusan}

Dimensi otonomi pengambilan keputusan yang dikatakan oleh Randall dan Svasand bahwasanya Partai akan menjadi Partai yang sempurna apabila Partai dapat menjalin hubungan baik dengan lingkungannya. Hubungan Partai mengacu pada jaringan-jaringan yang mendukung Partai. Berkaitan dengan hubungan Partai dengan aktor diluar parati, baik dengan otoritas tertentu (penguasa) maupun sumber dana (pengusaha atau lembaga luar) dan sumber dukungan massa.

Partai Golkar di Kabupaten Tanah Datar terkenal erat dengan masyarakat dibanding Partai lain, ini terlihat ketika adanya kegiatan-kegiatan yang dilakukan oleh Partai Golkar, masyarakat ikut serta meramaikan acara tersebut. Apalagi pemerintahan yang sudah didominasi oleh Partai Golkar sejak dulunya menjadikan Partai Golkar Partai primadona sesuai dengan penjelasan dari Ketua Partai Golkar Tanah Datar yakni

Hubungan Partai dengan masyarakat/ simpatisan, Partai dengan eksternal Partai : Partai Golkar pada tahun 2014 menjadi Partai Primadona, kenapa? Karena masyarakat sudah melihat hasil-hasil yang sudah dilaksanakan oleh Partai Golkar ,masyarakat melihat kondisi pada waktu itu Partai Golkar ini bisa menjadi penyambung aspirasi mereka, sehingga akhirnya Partai Golkar kembali menjadi pimpinan di Kab Tanah Datar, jadi hubungan kita di luar sangat bagus, bagaimanapun sebuah Partai politik harus membangun komunikasi yang bagus dengan masyarakat, kenapa? Karena dukungan dari masyarakat itulah yang akan menentukan kelanjutan dari Partai politik itu sendiri.

Komunikasi antar Partai politik tentulah harus dijaga. Ini yang selalu diingatkan kepada seluruh kader Partai Golkar akar membangun silaturahmi yang baik, baik itu sesama kader, anggota, pengurus maupun masyarakat

Hubungan yang erat dan kuat antara Golkar dengan lingkungannya memang sangat jelas sekali peneliti saksikan. Pengaruh dari jaringan-jaring yang memadai dapat membuat Partai Golkar mendominasi di Kabupaten Tanah Datar. Sesuai dengan apa 
yang dijelaskan oleh Randall dan Svasand dalam teorinya bahwa hubungan Partai dengan lingkungannya akan sangat mempengaruhi terbentuknya Partai yang sempurna. Apalagi jika benar-benar dikelola dengan sebaik mungkin, dipelihara dalam jangka waktu yang lama maka nanti akan menimbulkan kepercayaan dan keyakinan masyarakat untuk memilih Partai tersebut.

\section{Dimensi Reifikasi}

Dimensi reifikasi yang artinya bahwa bagaimana Partai mampu memberikan citra ke publik yang mampu mengangkat nilai kesetiaan konstituen dalam memberikan dukungannya. Seperti pada data awal penelitian ini bahwa ada masyarakat yang mengatakan bahwa beliau sudah sangat percaya kepada Partai Golkar, Partai Golkar ini sudah mendarah daging di dalam keluarganya. Ini salah satu bukti bahwa Partai Golkar dapat menciptakan kepercayaan masyarakat terhadapnya.

Apa yang dijelaskan Randall dan Svasand tentang reifikasi tidak hanya tentang bagaimana Partai mengangkat citra untuk mampu dipercaya oleh masyarakat tapi juga tentang berkaitan dengan bagaimana Partai mampu menjelmakan institusinya sebagai institusi yang memiliki nilai positif dan membawa dampak positif dalam mendapatkan pilihan konstituen sebanyak-banyaknya, dalam artian meraup suara dalam pemilu sebanyak-banyaknya.

Salah satu cara Partai Golkar dalam mewujudkan citra positif dari masyarakat dijelaskan oleh pengurus Golkar yang mengatakan bahwa :

..Cara kami mempengaruhi masyarakat adalah kader-kader selalu masuk ke dalam organisasi masyarakat baik tingkat Kabupaten, kecamatan, nagari dan jorong. Jadi ada dalam kelompok-kelompok masyarakat harus ada orang Golkar masuk ke dalamnya. Contohnya apapun organisasi orang di kecamatan atau nagari, kader Golkar harus ada terlibat disana kalau bisa menjadi ketua di organisasi tersebut, contoh pak wakil bupati, yang menjadi ketua Golkar saat ini masuk ke keseluruhan masyarakat, karena itulah ilmu politik, maka dari itu kader kader Golkar memang merajalela di organisasi masyarakat, dan kami membangun citra yang baik selama proses kedekatan dengan masyarakat.

Keikutsertaan kader Golkar pada setiap organisasi-organisasi masyarakat inilah yang memicu adanya kepercayaan masyarakat. Dari pertemuan-pertemuan yang diadakan bersama hingga tingkat bawah lapisan masyarakat, kemudian ikut serta dalam pengambilan keputusan musyawarah nagari menjadikan Golkar Partai aktif. Beberapa program pun dari Partai Golkar mudah dan cepat terlaksana akibat dorongan dan bantuan dari masyarakat. Partai politik tidaklah hanya untuk memenangkan calon saja tapi Partai politik sejatinya haruslah memiliki peranan penting dalam memberikan dampak positif bagi orang banyak. 


\section{Temuan Baru Penyebab Adanya Dominasi Partai Golkar di Kabupaten Tanah Datar}

Berdasarkan beberapa temuan tentu peneliti juga membandingkan dengan hasil penelitian terdahulu bahwasanya ada perbedaan dengan temuan sebelumnya, bahwa temuan peneliti mengungkapkan kebaruan sebagai pembanding dari pemakaian teori pelembagaan selain dari apa yang peneliti pakai. Masih berlaku dan dirasakan masyarakat Kabupaten Tanah Datar terkait sistem orde baru bahwa PNS memilih Partai Golkar. Adanya peran niniak mamak dalam hal ini datuak-datuak yang berafiliasi politik ke Golkar. Dominannya pengaruh datuak dalam kemenangan Golkar karena datuak adalah tokoh yang disegani oleh masyarakat sehingga pilihan parpol condong kepada pilihan sang datuak masa itu dan berpengaruh pada masyarakatnya. Ada beberapa datuak-datuak yang berada pada elit pemerintah yang berasal dari Partai Golkar, seperti menjabat sebagai anggota dewan dan pimpinan kecamatan.

\section{KESIMPULAN}

Kemenangan dan dominasi Partai Golkar telah dirasakan oleh rakyat dan terlihat jelas baik di tingkat Nasional maupun Lokal. Hasil penelitian ini menemukan bahwa penyebab Partai Golkar yang dominan adalah karena 1) manajemen organisasi sistemik, 2) penerapan platform partai suara Golkar, suara rakyat, nilai-nilai yang ditanamkan dalam anggota, 3) ada jaringan yang memberikan dukungan seperti tokoh masyarakat, tokoh ulama, hingga strata masyarakat. 4) citra positif yang telah dibangun oleh Partai Golkar kepada masyarakat, penggunaan budaya masyarakat untuk lebih dekat dan menarik pemilih. Temuan lain dalam penelitian ini adalah masih dirasakan terkait sistem Orde Baru oleh Pegawai Negeri Sipil (PNS) memilih Partai Golkar dan ada juga peran kelompok tradisional atau kearifan lokal yang memiliki afiliasi politik dengan Golkar.

\section{DAFTAR PUSTAKA}

Afifuddin, B. A. 2009. Metodologi Penelitian Kualitatif. Bandung: CV. Pustaka Setia. Budiarjo, Miriam, 2002. Dasar-Dasar Ilmu Politik. Jakarta: PT Gramedia Pustaka Utama. Bungin, B. 2011. Metodologi Penelitian Kualitatif. Jakarta: Rajawali Press. Huntington, S. (1973). Political Order in Changing Societies. New York : Yale University Press.

Firmanzah,2008. Mengelola Partai Politik, Jakarta: Yayasan Obor Indonesia Moleong, L. J. 2002. Metode Penelitian Kualitatif. Jakarta: PT. Remaja Rosdakarya. Nugroho, Riant.2014. Public Policy. Jakarta: PT. Elex Media Komputindo

Sigit Pamungkas. 2011. Partai Politik . Yogyakarta: Institute for Democracy and Welfarism.

Soekanto, S. 1984, Beberapa Teori Sosiologi Tentang Struktur Masyarakat. Jakarta : CV. Rajawali 
Tanjung, Akbar. 2008. The Golkar Way: Survival Partai Golkar di Tengah

Turbulensi Politik Era Transisi. Jakarta: PT Gramedia

Tomsa, Dirk. 2008. Party Politics and Democratization in Indonesia. London\&New York: Routledge, Publish By Taylor and Francis e- Library (2008)

Usman, Husein, 1995. Metode Penelitian Sosial, Jakarta : Bumi Aksara

Vicky Randall dan Lars Svasand. 2002. Party Institutionalization In New Democracies. Sage Publications

Frederikus Nong Wair, Hslarmiyati, Faktor-Faktor Penyebab Turunnya Dominasi Partai AKP dalam Pemilu Legislatif Turki Tahun 2015, Jurnal FISIP UPN, Vol 19, No 1. Maret 2015, Yogyakarta

Moch. Nurhasim, 2012 Dominasi Partai Aceh Pasca Mou Helsinki, Jurnal Penelitian Politik:LIPI. e-ISSN Vol 9.No 2.

Moreau dalam Fionna, 2009, Golkar: The Embodiment of New Order that Still Appeals, Indonesian Journal of Social Sciences, Vol I. No.3

Muhammad Ridha T.R, 2016, Dilema pelembagaan paartai Golkar di tingkat lokal:Fenomena politik klan, Jurnal Ilmu Pemerintahan Universitas gajah Mada.Cosmogov Vol 2 No 1 Yogyakarta

Imansyah, Teguh,2012, Regulasi Partai politik dalam mewujudkan penguatan peran dan fungsi kelembagaan Partai politik. Jurnal Rechtsvinding, Vol 1 No.3 Jakarta

Irvan Ansyari dkk, 2015, Analisis kemenangan Partai Golkar di Kabupaten Tanah Datar sejak pemilihan umum legislatife 1999 ditinjau dari perspektif patron klien,. Jurna Ilmu pemerintahan. Vol 1 No 1 Semarang

Simanjuntak, B. A. 2005. Strategi Dominasi dan Keutuhan Negara Bangsa yang Pluralistik. Jurnal Antropologi Sosial Budaya ETNOVISI , 1 (2).

Vicky Randall dan Lars Svasand. 1999. Party Institutionalization and the New Democracies. ECPR Joint Session of Workshop, 26-31 Maret, Mannheim : ECPR. http://www.kbbi.web.id/dominasi. Diakses pada 02 Januari 2019 pukul 14.00 WIB. 